\title{
Jak jsme na tom?
}

Jiří Štefanides

Za poslední pětiletí přinesl výzkum historie německojazyčného divadla na Moravě a ve Slezsku několik nových výsledků, a to zejména na dvou vysokoškolských pracovištích, na filozofických fakultách univerzit v Brně a v Olomouci. Margita Havlíčková, autorka už starší práce o divadle v Brně v letech 1668-1733 (HAVLÍČKOVÁ 2012), se posléze soustředila na působení herce a principála Johanna Georga Gettnera, rodáka z Mikulova, v rakouském prostoru na konci 17. století (HAVLÍČKOVÁ a NEUHUBER 2014). Olomoučtí historici z Katedry muzikologie vydali rovněž před sedmi lety obsáhlou dvousvazkovou práci věnovanou olomoucké opeře v letech 17701920 (KOPECKÝ a KŘUPKOVÁ 2012), byl to výsledek úspěšně dokončeného projektu Grantové agentury České republiky. V poslední době se soustředili na její uplatnění v zahraničí. V mírně upravené podobě a bez soupisu operního repertoáru vyšla nejprve v Olomouci anglicky (KOPECKÝ a KŘUPKOVÁ 2015) a pak v Regensburgu německy (KOPECKÝ a KŘUPKOVÁ 2017). A na olomoucké Katedře divadelních a filmových studií byl ve spolupráci se studenty germanistiky pořízen soupis repertoáru a členstva městského divadla v Moravské Ostravě za jeho první období v letech 1907-1919, kdy mělo pouze německy hrající soubor (SCHREIBEROVÁ a ŠTEFANIDES 2018).

Co ovšem je opravdovým př́slibem pro budoucnost, to je několik diplomových a dizertačních prací, obhájených i rozepsaných, jejichž autoři našli odvahu pustit se do stále málo probádaného terénu německojazyčné divadelní kultury. V roce 2018 obhájil dizertaci věnovanou dějinám divadla v Mikulově od nejstarších dob do roku 1944 Miroslav Lukáš. Práce je postavena na rozsáhlém studiu pramenů a hodnota obrazu zdejšśho divadelního života daleko přesahuje hranice jednoho města a nedávno ji vydala knižně Masarykova univerzita (LUKÁŠ 2019). Stejně jako Lukáš, i několik dalších doktorandek se věnuje výzkumu německy hraného divadla pod vedením Margity Havlíčkové. Klára Škrobánková se zaměřuje na starši dějiny městského divadla v Opavě, ale už ve své magisterské diplomové práci si jako téma vybrala osobnost direktora Carla Josepha Schwertbergera a působení jeho společnosti v českých zemích v 18. století (ŠKROBÁNKOVÁ 2015). Pavla Pinkasová píše práci o režiséru $R u$ dolfu Beerovi, který vedl dvě sezony v letech 1919-1921 spolkové německé divadlo v Brně a vytvořil zde pravděpodobně nejvýznamnější podobu divadelního expresionismu na Moravě. Ilona Horváthová se věnuje dějinám městského divadla ve Znojmě.

Další dvě studentské práce vznikly v Olomouci. Rovněž inscenacemi expresionistické dramatiky, tentokrát ve spolkovém Německém divadle v Moravské Ostravě, a širším kontextem včetně vlivu na česká divadla na Moravě a ve Slezsku se ve své magisterské práci zabývá Tereza Bednarská (BEDNARSKÁ 2017). Lenka Schreiberová obhájila magisterskou práci věnovanou ostravskému působení berlínského herce a režiséra Hermanna Vallentina, pozoruhodné postavy, jež se mimo jiné významně zapsala do německého němého filmu 
(SCHREIBEROVÁ 2016). Vallentin musel pro svůj židovský původ emigrovat z Německa a v letech 1935-1938 byl angažován v Německém divadle v Moravské Ostravě. Tato jeho ostravská epizoda nebyla dosud $\mathrm{v}$ zahraniční literatuře reflektována. A v Olomouci rovněž vzniká jedna dizertační práce: vedoucí divadelního oddělení Slezského zemského muzea v Opavě Sylva Pracná má před obhajobou monografie věnované historii městského divadla v tehdy německém Krnově v letech 1854-1944. Dizertace obsahuje i známý odehraný repertoár.

Všechny tyto práce mají jedno společné: jsou to plody základního výzkumu. Při hmotné neexistenci divadelního artefaktu jsou založeny na nutné pozitivistické excerpci a vyhodnocování pramenů, k syntézám může docházet jen u přesně vymezených a méně rozsáhlých témat. Výzkum je orientován spíše teritoriálně a institucionálně, především na Brno, Moravskou Ostravu, Olomouc a Opavu. V Olomouci dokonce vznikla jedna práce, která je jistou raritou: Jiř́i Kučera, neškolený muzikolog-teatrolog, člen operního sboru Moravského divadla v Olomouci, věnoval několik let obsáhlé práci o olomoucké opeře za dob Františka Josefa I. (KUČERA 2018). Zaměřil se především na zpěváky a jeho výklad, vedle obsáhlé obrazové a faktografické dokumentace, je v podstatě důkladným převyprávěním dobové kritické reflexe operních představení v olomouckém tisku. Práci chybí žádoucí odborný kritický odstup a uplatnění muzikologické analýzy i zobecnění, ale přinejmenším svědčí o tom, že historie německy hraného divadla u nás je pocitována jako aktuální badatelské téma.

Méně viditelně se rozvíjí výzkum v další podstatné a žádoucí linii, jíž jsou osobnosti - práce Havlíčkové a Neuhubera o Gett- nerovi či Škrobánkové o Schwertbergerovi jsou spíše výjimkou. Byli to ale především ředitelé a herci, kteří propojovali divadelní život Moravy a Slezska se středoevropským prostorem a velmi rychle přinášeli do regionu nové podněty, impulzy, témata. Je to ovšem právě proto badatelská „disciplína" velmi náročná: představuje zpravidla obsáhlý výzkum plošný i časový. $\mathrm{V}$ tomto směru je velmi užitečná elektronická databáze dalšího teprve vznikajícího svazku České divadelní encyklopedie, který je věnován německé činohře 19. století v českých zemich. V současné době obsahuje kromě jiných už kolem dvaceti hesel osobností, zejména divadelních ředitelů, kteří větší nebo menší část svého působení spojili s Moravou a Slezskem. Vznikající encyklopedie je smysluplná a potřebná i proto, že vytváří badatelskou poptávku a pomáhá tak rozšiřovat okruh autorů, kteří jsou ochotní se tématu věnovat.

Pokusíme-li se o hodnocení výsledků zdejš́ho výzkumu, mohli bychom je shrnout takto: Po třiceti letech od sametové revoluce máme $\mathrm{k}$ dispozici alespoň rámcovou představu o institucionální povaze divadelního života $\mathrm{v}$ devatenácti městech Moravy a Slezska, která měla výraznou většinu obyvatel hovořících německy - z nich v deseti byla potvrzena existence městského divadla. Zřetelně se ukazuje, že v těchto dvou korunních zemích se utvářel okruh společností a ředitelů, kteří svou kariéru spojili především s tímto regionem. Zároveň bylo toto území cílem čím dál častějších zájezdů souborů z německy mluvících zemí, včetně špičkových - vídeňský Burgtheater či dvorní opera zajížděly třeba i do Šumperka, dnes něco sotva představitelného. Pozoruhodný byl způsob adaptace převážně německých měst na vznik Československa - divadelní kultura v nich nejen 
plnila národně obranný program, ale opět přiváděla do Československa mnoho divadelních impulzů ze zahraničí.

Je to málo, je to hodně? U vědomí rozsáhlosti tématu, německy hrané divadlo dominovalo v moravsko-slezském prostoru od poloviny 17. století do roku 1918 a mnohde až do konce druhé světové války, máme (podle mého setrvale skeptického mínění) za sebou jen nepatrnou část nutného výzkumu. Přitom už nynější nepočetné sondy prokazují nejen rozdíly, ale i úzké sepětí a sounáležitost divadelních kultur německé a české. Divadelní vývoj na Moravě a ve Slezsku se dlouho odbýval mimo bezprostřední vliv české Prahy, naopak byl pod intenzivním vlivem divadla vídeňského. Jeho funkce, proměny a popularita se rychle přenášely přes Brno, Olomouc a Šumperk do Opavy a Moravské Ostravy. Například pořízení něčeho takového jako je „divadelní atlas“ by určitě lépe ozřejmilo pozoruhodné časoprostorové amplitudy pohybu divadelních koncepcí, institucí, divadelních společností a osobností vídeňského divadelnictví $\mathrm{v}$ tomto prostoru, a zároveň pronikání česky hraného profesionálního divadla do tohoto regionu od druhé poloviny 19. století.

Jako povzbuzující př́íslib nadějnějších perspektiv a urychlení dalšího výzkumu se jeví hned tři projekty, které shodou okolností vznikají mimo moravsko-slezský region. Brzy bude dokončen rozsáhlý projekt zpracování divadelních pramenů v rámci podpory NAKI II Cesta $k$ divadlu, který zpř́stupní i soubory pramenů $\mathrm{k}$ německy hranému divadlu. Podílejí se na něm pracovníci Národního muzea v Praze, Kabinetu pro studium českého divadla Divadelního ústavu a Moravského zemského muzea v Brně. Ve zmíněném Kabinetu se pak rodí realizace myšlenky zř́idit a postup- ně budovat elektronickou databázi osobností, instituci a repertoáru, která by konečně umožnila centrální evidenci všech divadelních jevů s možností jejich časoprostorové komparace. A ten třetí př́íslib: pro české badatele bude nepochybně velmi cennou pomůckou další impozantní práce berlínského divadelního bibliografa Paula S. Ulricha, s jejímž vydáváním začal vídeňský Don Juan Archiv. Jeden ze svazků bude věnován českým zemím a přinese dosud nejúplnější bibliografické zpracováni a excerpci divadelnich almanachů a ročenek, které se týkají míst, ředitelů, souborů, jež se u nás vyskytovaly v letech 1777-1918 (ULRICH [2019]). S touto pomůckou se pro české badatele podstatně rozšírí možnosti výzkumu, včetně témat pro studentské absolventské práce. Ukazuje se zřetelně, že efektivita časově náročného výzkumu bude vyšší, čím intenzivněji bude realizován na bázi mezinárodní spolupráce - přinejmenším ve stejném prostoru, v němž se tehdy odbýval divadelní život, společný pro obyvatele střední Evropy (čti: tehdejšího rakouského mocnářství), prostor rozmanitý, otevřený, multikulturní, poskytující čas od času divadelní impulzy celé Evropě.

Česká divadelní historiografie bezprostředně po listopadu 1989 explicitně vyjádřila vědomí nutnosti pustit se do výzkumu a "naše německé divadlo" chápat jako integrální součást obrazu dějin divadla v českých zemích. Učinil tak jménem redakce Divadelni revue Evžen Turnovský v editorialu posledního čísla v roce 1990 (TURNOVSKÝ 1990). V závěru svého dodnes aktuálního pojmenování a výčtu problémů přislíbil, že Divadelni revue „bude čas od času, pokud možno s jistou pravidelností, zveřejňovat pracovní výsledky“. To mě zaujalo, zejména proto, že právě výzkum na Moravě a ve Slezsku 
stojí téměř zcela mimo pozornost současné redakce. Jeví-li se Divadelni revue jako tribuna reprezentující navenek mimo jiné i stav současné české divadelní historiografie, pak výzkum na mimopražských pracovištích se odbývá jakoby téměř v utajení a hlavně: jeho výsledky se nestávají, zbaveny odborné percepce, součástí celooborového vědomí, natož řešení, o potřebě případné diskuse metodologické nemluvě. Dílčí práce přitom samozřejmě vznikají i na mimopražských pracovištích v Čechách. Čtyřsvazkové akademické Dějiny českého divadla, metodologicky postavené na jazykově vymezené koncepci národního obrození, nám rychle zastarávají, ale abychom dokázali vnímat a popsat naši divadelní kulturu jako historicky se vyvíjející multikulturní jev, k tomu máme stále daleko...

\section{Bibliografie}

BEDNARSKÁ, Tereza. 2017. Expresionistické drama v Deutsches Theater v Morauské Ostravě $v$ letech 1919-1938. Magisterská diplomová práce. Univerzita Palackého v Olomouci, Filozofická fakulta, Katedra divadelních a filmových studií, 2017.

HAVLÍČKOVÁ, Margita. 2012. Berufstheater in Brünn 1668-1733. Brno: Masarykova univerzita, 2012.

HAVLÍČKOVÁ, Margita a Christian NEUHUBER. 2014. Johann Georg Gettner und das barocke Theater zwischen Nikolsburg und Krumau. Brno: Masarykova univerzita, 2014.

KOPECKÝ, Jiří a Lenka KŘUPKOVÁ. 2012. Německá operni scéna v Olomouci. I. 1770-1878.
II. 1879-1920. Olomouc: Univerzita Palackého, 2012.

KOPECKÝ, Jiří a Lenka KŘUPKOVÁ. 2015. Provincial Theatre and Its Opera. German Opera Scene in Olomouc (1770-1920). Edice Konvikt. Olomouc: Vydavatelství Filozofické fakulty UP v Olomouci, 2015.

KOPECKÝ. Jiří a Lenka KŘUPKOVÁ. 2017. Das olmützer Stadttheater und seine Oper. „Wer in Olmütz gefällt, gefällt der Ganze Welt." Neue Wege. Schriftenreihe des Sudetendeutschen Musikinstitut. Regensburg: ConBrio Verlagsgesellschaft, 2017.

KUČERA, Jiří. 2018. Opera v olomouckém divadle za Františka Josefa I. Praha: powerprint, 2018. LUKÁŠ, Miroslav. 2019. Divadlo v Mikulově za éry rodu Dietrichsteinu. Brno: Muni Press, 2019.

SCHREIBEROVÁ, Lenka. 2016. Berlinský herec Hermann Vallentin v Moravské Ostravě. Magisterská diplomová práce. Univerzita Palackého v Olomouci, Filozofická fakulta, Katedra divadelních a filmových studií, 2016.

SCHREIBEROVÁ, Lenka, Jiří ŠTEFANIDES a kolektiv. 2018. Městské divadlo v Morauské Ostravě / Das Stadttheater in Mährisch Ostrau 1907-1919. Repertoár a členstvo / Repertoire und Mitgliederschaft. Edice Divadlo, sv. 7. Olomouc: Univerzita Palackého, 2018.

ŠKROBÁNKOVÁ, Klára. 2015. Carl Joseph Schwertberger a jeho působeni v českých zemich. Magisterská diplomová práce. Masarykova univerzita, Filozofická fakulta, Katedra divadelních studií, 2015.

TURNOVSKÝ, Evžen. 1990. Naše německé divadlo. Divadelní revue 4 (1990): 3-4.

ULRICH, Paul S. [2019]. Deutschsprachiges Theater in Tschechien (1777-1918). Dokumentation zu Topographie und Repertoire anhand von universalen Theateralmanachen und lokalen Theaterjournalen. Wien: Don Juan Archiv, [2019]. (Před vydáním.) 